Asian Journal of Contemporary Education

DOI: $10.184 .88 /$ journal.137.2017.11.1.9

Vol. 1, No. 1, 1-9

(C) 2017 AESS Publications. All Rights Reserved.

URL: www.aessweb.com

\title{
FIVE-YEAR LICENSURE EXAMINATION PERFORMANCE OF LIBRARY AND INFORMATION SCIENCE GRADUATES
}

\author{
Elizabeth A. Lascano ${ }^{1+}$ \\ Apler J. Bansiong ${ }^{2}$
}

${ }^{1.2}$ College of Teacher Education, Benguet State University, Philippines

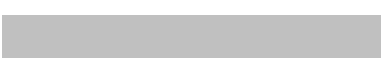

\section{Article History}

Received: 25 July 2017 Revised: 10 August 2017 Accepted: 14 August 2017 Published: 25 August 2017

\section{Keywords}

Curricular programs

Librarians' licensure examination

(LLE)

Passing rates

Bachelor of library and

information science (BLIS)

Center-Reviewees

Self-Reviewees

First timers

Repeaters.

\section{ABSTRACT}

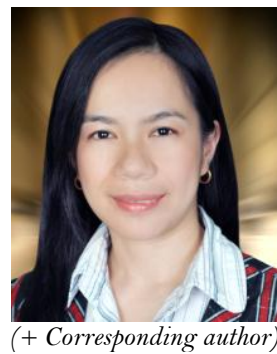

Licensure examination performance of graduates is one measure of the effectiveness of curricular programs. This study analyzed the five-year performance of 159 BLIS graduates in the Librarians' Licensure Examination in from 2011 to 2015. Findings reveal that the passing the graduates' passing rates were statistically consistent in the five-year duration. The average passing rate was moderately high at $57.89 \%$, but the mean general rating was only $73.23 \%$. The general ratings had a slightly platykurtic, negatively skewed distribution. Overall, the institutional passing rate surpassed the national passing rate by $45.12 \%$. Passing rates were highest in Information Technology, Indexing and Abstracting, and Library Organization and Management. Lower passing rates were posted in Selection and Acquisition of Library Materials, and in Cataloguing and Classification. The first timers, and the review center attendees, outperformed their respective counterparts, while the male and female examinees were statistically even. The first timers scored better than the repeaters in five areas, save cataloguing and classification. Meanwhile the male examinees and the center-reviewers were better than their counterparts on only one area - Library Organization and Management, and Selection and Acquisition of Library Materials, respectively. Recommendations as to the result of this study were proposed.

Contribution/ Originality: This study is one of the very few studies which have investigated the result of licensure examination of librarians in the Philippines. The paper's primary contribution is finding that the alumni's performance varied significantly across the six examination areas. Also, the first timers outperformed the repeaters in passing rates.

\section{INTRODUCTION}

The effectiveness of a curricular program is almost always gauged in the graduates' employability and their passing performance in licensure examinations (Visco, 2015; Tan, 2016). For private higher-education institutions (HEIs), the licensure examination performance of alumni has become a source of prestige and a force that attracts prospective enrollees. For state universities and colleges (SUCs), it partly determines the budget the institution receives since licensure examination performance is one of the output indicators of the normative funding scheme in the allocation of expenditures to SUCs (Ladia and Nool, 2012). Because of these reasons, higher education 
institutions are giving much attention to the licensure examination performance of their graduates (Tarun et al., 2014).

The Philippine government recognizes the significant role librarians and other information professionals play in the development of information-literate citizens. As such, two laws have been enacted to improve and strengthen library service and practice in the country. These laws are the Philippine Librarianship Act of 1990 (RA no. 6966) which was later repealed by RA no. 9246 (Ramos et al., 2013). The enactment of these laws have paved way for the offering of Library Science, which later was renamed Library and Information Science. The former used to be a specialization course under the Education program. As for the latter nomenclature, it is the option of the institution to retain it with education, or to bring the degree to the college offering Information and Computer Science (CMO No. 8, s. 2005).

The change in the degree's nomenclature has resulted from the rapid developments in the field of information and communications technology (ICT). Such developments have drastically changed the way librarians work (Ramos et al., 2013; Maghuyop, 2016). ICT competence has become necessary in the field of information organization and dissemination, aside from the traditional library and information skills.

To practice the profession as a librarian, students must enroll in the degree Bachelor of Library and Information Science. After graduation, they must pass the Librarian's Licensure Examination (LLE). Successful examinees will be given certificate of registration and a professional identification card.

The Librarian's Licensure Examination (LLE) covers six major subject areas. These are Library Organization and Management (Area 1), Reference, Bibliography and User Services (Area 2), Selection and Acquisition of Library Materials (Area 3), Cataloguing and Classification (Area 4), Indexing and Abstracting (Area 5), and Information Technology (Area 6). To pass the LLE, the examinee must obtain a general weighted average of 75 , with no grade lower than $50 \%$ in any of the six subject areas (Ramos et al., 2013)(Sec. 6, RA no. 9246, 2004).

Report from the PRC's Board of Librarians indicates that the results of the LLE have been declining from 2004 to 2013 (Ramos et al., 2013). This is definitely not good news as the Philippines is currently experiencing a shortage of licensed librarians. The Board for Librarians and institutions offering LIS must continuously study results of examinations and determine the factors that could adversely affect licensure performance.

Most studies on licensure results seek to evaluate performance of graduates to allow institutions to appraise their curricular offerings and come up with plans, policies, and programs that will hopefully improve their future graduates' performance (Chan-Rabanal, 2016). Many of these studies sought how examinee-related and nonexaminee-related factors could influence licensure performance. The examinee-related factors include cognitive states such as high school and college grade-point average (GPA), college entrance score, among others (Soriano, 2009; Ferrer et al., 2015; Chan-Rabanal, 2016). The non-cognitive examinee-related factors are age, gender, learning style, specialization, home and family background, and attendance to review class (Soriano, 2009; Tarun et al., 2014; Ferrer et al., 2015; Visco, 2015; Tan, 2016).

The other factors considered as determinants to licensure exam performance are teacher qualities and administrative support and supervisory policies. Teacher qualities include experience and educational attainment, while administrative and supervisory matters include retention policies, availability of facilities, etc.

There are few studies on the factors influencing LLE performance of graduates. Ramos et al. (2013) reported that age, gender, and examinee type (first-timer or repeater) did not significantly affect the national LLE performance from 2006-2010. Meanwhile, when an institutional performance was considered for a span of 10 years, Maghuyop (2016) found an insignificant relationship between English grade and LLE performance. However, college GPA was seen to influence passing performance. Finally, Merced and Canang (2014) noted in a regionalwide study that school facility, mental ability of the examinee, and economic stability of the examinee's family, are all significant contributors in hurdling the LLE. 
This present study is geared towards examining the five-year trend in the LLE performance of BLIS graduates in a Teacher-Training Institution in Benguet. It particularly aimed to provide a detailed report on the LLE performance of the graduates per test schedule on the five-year period from 2011-2015. It also aims to analyze the performance of each graduate on each of the six areas in the test, and find out how each area relates with the examinees' overall rating. This is a feature of this research absent in earlier studies on LLE performance.

The data generated from this study will provide pertinent information that will influence future policy formulations and curricular enhancement, and intervention efforts from the administrators and stakeholders of the University and the College. For instance, it might be helpful to find out which examination areas are the graduates not performing well, or which subject areas are difficult and therefore needs more emphasis and intervention. Finally, the result of this study will determine if the subsidy granted to BSU as a state institution of higher learning had been worthwhile.

This study is conducted to analyze the five-year passing performance of BLIS graduates of a Teacher-Training Institution in the Librarian Licensure Examination (LLE). Specifically, it sought to answer the following questions:

1. What is the five-year passing rate of the BLIS graduates in the LLE?

2. What is the difference in the LLE passing rates of the BLIS graduates and the national passing rate in the last five years?

3. What is the five-year passing profile of the CTE graduates along the six LLE areas?

4. What is the difference in the five-year passing rates of BLIS Graduates in the LLE when compared according to:
a. Sex
b. Number of takes
c. Attendance to review classes

\section{METHODOLOGY}

This study used the descriptive - correlation method of research. Documentary analyses are the main methods used in this study. The LLE results of five examinations from 2011 to 2015 were obtained from the Professional Regulations Commission (PRC) of the Philippines.

Passing rates or percentages of all 159 graduates were used to indicate LLE performance, as institutions are gauged based on these parameters. General ratings were also included to describe overall trends of performance.

Since the dependent variable is a categorical variable, i.e., passed or failed, the chi-square test was used to determine significant differences among the variables.

Passing rates were interpreted, based on Maghuyop (2016) as follows:

$\begin{array}{ll}81 \%-100 \% & \text { Very High } \\ 61 \%-80 \% & \text { High } \\ 41 \%-60 \% & \text { Moderately High } \\ 21 \%-40 \% & \text { Low } \\ 0 \%-20 \% & \text { Very low. }\end{array}$

\section{RESULTS AND DISCUSSION}

3.1. Performance of BLIS Graduates in the LLE from $2011-2015$.

\subsubsection{In terms of Passing Rates}

The over-all passing performance of the BLIS graduates from 2011-2015 is moderately high at 57.89\% (Table 1), although passing rates are high in three examinations. The lowest passing rate among the BLIS graduates was recorded in the April 2014 examination. 
Asian Journal of Contemporary Education, 2017, 1(1): 1-9

Table-1. Five-year Passing Rates of BLIS Graduates in the LLE.

\begin{tabular}{l|l|l|l|l}
\hline Date Of Exam & Passers & Flunkers & Passing Rate $(\%)$ & Interpretation \\
\hline November 2011 $(\mathrm{N}=21)$ & 15 & 6 & 71.43 & High \\
\hline November 2012 $(\mathrm{N}=31)$ & 19 & 12 & 61.29 & High \\
\hline November 2013 $(\mathrm{N}=47)$ & 25 & 22 & 53.19 & Moderate \\
\hline April 2014 $(\mathrm{N}=21)$ & 8 & 13 & 38.10 & Low \\
\hline August 2015 $(\mathrm{N}=39)$ & 25 & 14 & 64.1 & High \\
\hline FIVE-YEAR PASSING \% & 92 & 67 & 57.89 & Moderate \\
\hline $\mathrm{X}^{2}$ statistic & $X_{0.05}^{2}=9.49$ & $X^{2}{ }_{0.01}=13.28$ & $X^{2}=6.14 n s$ & \\
\hline
\end{tabular}

Source: Philippine Professional Regulations Commission, Board of Librarians

Despite the differences in the interpretations, $X^{2}$ values at $p=0.01$ and $p=0.05$ indicate that the passing rates do not significantly differ. This result is similar to the passing rates of BSE and BEE graduates of the same institution in the Licensure Examination for Teachers (LET) for a five-year period, covering nine examinations (Botengan et al., 2016).

The passing performance of the BLIS graduates was higher than that of the graduates of University of Mindanao from 2002 to 2012, which is 38.42\% (Maghuyop, 2016).

The lowest performance in the April 2014 LLE can be explained by the composition of the examinees in this schedule. Analysis indicate that all but one of the 21 examinees were repeaters. It has been proven in many analysis that repeaters do not perform well in examinations (Corpuz and Quinon, 2009; Navarro et al., 2015) and they often contribute to an institution's decrease in overall passing rate.

\subsection{According to General Ratings}

The overall general rating of the BLIS graduates in five LLE are moderately high at 73.23\% (Table 2).

Table-2. General ratings of BLIS Graduates in five LLEs.

\begin{tabular}{l|l|l|l|l|l}
\hline Date Of Exam & Mean & Se & Stdev & Skewness & Kurtosis \\
\hline November 2011 $(\mathrm{N}=21)$ & 76.84 & 0.85 & 3.89 & -0.475 & -0.331 \\
\hline November 2012 $(\mathrm{N}=31)$ & 72.28 & 1.56 & 8.71 & -2.401 & 7.700 \\
\hline November 2013 $(\mathrm{N}=47)$ & 73.22 & 0.92 & 6.29 & -0.633 & 0.265 \\
\hline April 2014 $(\mathrm{N}=21)$ & 68.61 & 1.49 & 6.84 & -0.762 & -0.569 \\
\hline August 2015 $(\mathrm{N}=39)$ & 74.43 & 1.10 & 6.87 & -1.000 & 0.226 \\
\hline FIVE-YEAR PASSING \% & 73.23 & 0.56 & 7.08 & -0.412 & 3.452 \\
\hline
\end{tabular}

Source: Philippine Professional Regulations Commission, Board of Librarians

Similar with the result on passing rates, the highest mean general rating was posted by the examinees in November 2011, followed by those who took the LLE in August 2015. Again, the lowest mean general rating was recorded among the examinees in April 2004.

The general ratings were negatively skewed in four examinations, indicating higher median scores than mean scores. This means that more students scored above the mean. The kurtosis of 3.452 indicates a slightly platykurtic distribution of scores (Ravetter and Wallnau, 2014). A platykurtic distribution means that the scores are spread quite well near the mean.

\subsection{Difference in the LLE Passing Rate of BLIS Graduates and the National Passing Rate from 2011-2015.}

Table 3 shows that while both the five-year institutional and national passing rates are moderately high, that of the former is higher by $18 \%$. The institutional passing rate has surpassed the national passing rate by $45.12 \%$. 
Table-3. Difference in the Five-year LLE Passing Rates of BLIS Graduates and the National Data

\begin{tabular}{l|l|l|l|l|l|l}
\hline \multirow{2}{*}{$\begin{array}{l}\text { Date of } \\
\text { Exam }\end{array}$} & \multicolumn{2}{|l|}{ Institutional Data } & \multicolumn{2}{l|}{ National Data } & $\begin{array}{l}\text { Differ- } \\
\text { Ence }\end{array}$ & $\begin{array}{l}\text { Surpas } \\
\text { Sing } \%\end{array}$ \\
\cline { 2 - 7 } & Passing \% & Inter. & Passing \% & Inter. & 158.62 \\
\hline November 2011 & 71.43 & High & 27.62 & Low & 43.81 \\
\hline November 2012 & 61.29 & High & 46.67 & Mod & 14.62 \\
\hline November 2013 & 53.19 & Mod & 45.92 & Mod & 7.27 \\
\hline $\begin{array}{l}\text { April 2014 } \\
\text { August 2015 }\end{array}$ & 38.10 & Low & 27.39 & Low & 10.71 & 39.10 \\
\hline $\begin{array}{l}\text { Five-Year Passing } \\
\%\end{array}$ & 54.1 & High & 47.04 & Mod. & 17.06 & 36.27 \\
\hline
\end{tabular}

Source: Philippine Professional Regulations Commission, Board of Librarians

Interestingly, in all five examinations, the institutional passing rate has surpassed the national passing rate in all five examinations. Apparently, in terms of surpassing percentages, the takers of the November 2011 LLE registered the best performance. The passing rates posted by this group of examinees were higher than the national data by more than $150 \%$.

The above result of consistently higher institutional passing rate is similar with the findings of Botengan et al. (2016) on their BSE and BEE graduates in the Licensure Examinations for Teachers. This was not the case in Maghuyop (2016) analysis, as their institutional passing rate was higher in six out of ten examinations.

The higher performance by the BLIS graduates than the national data can be an indication of the institution's commitment to unselfishly provide everything that students need to hurdle licensure examinations. In-house review classes are offered after graduation, and recently, the University has mandated the offering of course appraisal program in all board courses. Both review and course appraisal programs are intensively implemented and strictly monitored to prepare graduates for licensure examinations.

The institutional policy on admission and retention could also have contributed to the higher passing rates of the graduates. Added to this is the faculty and administrators' commitment to ensure quality instruction. With the faculty members who constantly update themselves with the current trends in issues in the field, students are prepared to hurdle licensure examinations, and ultimately, to meet the demands of the workplace.

\subsection{Five-Year Performance of BLIS Graduates in the Six LLE Areas.}

For the five-year examination periods, the BLIS graduates performed differently in all six areas (Table 4). These graduates performed best in Area 6 (Information Technology), Area 5 (Indexing and Abstracting), and Area 1 (Library Organization and Management). The lowest passing rates were seen in Area 3 (Selection and Acquisition of Library Materials), and Area 4 (Cataloguing and Classification). This result is very similar to the findings of Maghuyop (2016) on the performance of their BLIS graduates. Their graduates also performed best in Information Technology (Area 1), and lowest in Selection and acquisition of library materials (Area 3 ).

The results described have important implications to the institution's curriculum committee involved in Library and Information Science. The information on the weak areas among alumni in five examinations can provide ideas on what subjects to emphasize, both in instruction and in review. The enhancement, reform and innovation initiatives of the college must focus on these problematic areas.

The BLIS graduates' passing performance in all six areas was statistically different in all but in the April 2014 examination, where the passing rates were essentially even. Such discrepancy could be explained by the fact that 20 of the 21 examinees in this period were repeaters. There was just a single first-timer since the BLIS students were yet to graduate during the day of the examination. It seems that all six areas are equally challenging to this group of examinees. Such result must be seriously considered in future intervention programs. 
Table-4. Comparison of the Five-Year Performance of BLIS Graduates in the Six LLE Areas

\begin{tabular}{|c|c|c|c|c|c|c|}
\hline DATE OF EXAM & Area 1 & Area 2 & Area 3 & Area 4 & Area 5 & Area 6 \\
\hline \multicolumn{7}{|l|}{ November 2011} \\
\hline Passers & 17 & 18 & 8 & 15 & 20 & 21 \\
\hline Flunkers & 4 & 3 & 13 & 6 & 1 & $\mathrm{O}$ \\
\hline Passing $\%$ & 80.95 & 85.71 & 38.1 & 71.43 & 95.24 & 100 \\
\hline $\mathrm{X}^{2}$ sig. & \multicolumn{6}{|c|}{30.97 (sig at 0.001$)$} \\
\hline \multicolumn{7}{|l|}{ November 2012} \\
\hline Passers & 28 & 20 & 14 & 15 & 24 & 23 \\
\hline Flunkers & 3 & 11 & 17 & 16 & 7 & 8 \\
\hline Passing $\%$ & 90.32 & 64.52 & 45.16 & 48.39 & 77.42 & 74.19 \\
\hline $\mathrm{X}^{2}$ sig. & \multicolumn{6}{|c|}{$21.39(\mathrm{sig}$ at 0.001$)$} \\
\hline \multicolumn{7}{|l|}{ November 2013} \\
\hline Passers & 32 & 26 & 26 & 18 & 38 & 45 \\
\hline Flunkers & 15 & 21 & 21 & 29 & 9 & 2 \\
\hline Passing $\%$ & 68.09 & 55.32 & 55.32 & 38.3 & 80.85 & 95.74 \\
\hline $\mathrm{X}^{2}$ sig. & \multicolumn{6}{|c|}{$43.82(\operatorname{sig}$ at 0.001$)$} \\
\hline \multicolumn{7}{|l|}{ April 2014 } \\
\hline Passers & 9 & 9 & 8 & 9 & 12 & 10 \\
\hline Flunkers & 12 & 12 & 13 & 12 & 9 & 11 \\
\hline Passing $\%$ & 42.86 & 42.86 & 38.1 & 42.86 & 57.14 & 47.62 \\
\hline $\mathrm{X}^{2}$ sig. & \multicolumn{6}{|c|}{1.83 (not sig.) } \\
\hline \multicolumn{7}{|l|}{ August 2015} \\
\hline Passers & 28 & 31 & 17 & 30 & 25 & 23 \\
\hline Flunkers & 11 & 8 & 22 & 9 & 14 & 16 \\
\hline Passing $\%$ & 71.79 & 79.49 & 43.59 & 76.92 & 64.1 & 58.97 \\
\hline $\mathrm{X}^{2}$ sig. & \multicolumn{6}{|c|}{$12.915(\operatorname{sig}$ at 0.05$)$} \\
\hline \multicolumn{7}{|c|}{ Five-Year Passing Rate } \\
\hline Passers & 114 & 104 & 73 & 87 & 119 & 122 \\
\hline Flunkers & 45 & 55 & 86 & 72 & 40 & 37 \\
\hline Passing $\%$ & 71.70 & 65.41 & 45.91 & 54.72 & 74.84 & 76.73 \\
\hline $\mathrm{X}^{2}$ sig. & \multicolumn{6}{|c|}{50.10 (sig at 0.001$)$} \\
\hline
\end{tabular}

Critical value, $X^{s} \alpha, \mathrm{df}=10.05=3.84,0.01=6.64$

\subsection{LLE passing rates of BLIS Graduates when Compared According to the Examinee Variables}

Table 5 shows that the passing rates of BLIS graduates are significantly higher among first timers and those who attended review centers. However, although the passing rates of males were high and the females moderately high, their passing rates are statistically tied. The mean passing rates of the first timers were high while that of the repeaters was low. Meanwhile, those who attended review sessions posted a high passing rate, while those who did not attend review centers registered moderately high passing rates.

Table-5. Five-Year Overall passing rate of BEE Graduates compared according to the examinee variables

\begin{tabular}{l|l|l|l|l|l}
\hline Variables & Passers & Flunkers & Passing \% & $\boldsymbol{X}^{2}$ Stat & Significance \\
\hline First timers & 76 & 38 & 66.67 & 12.36 & Sig. at $p=0.001$ \\
\hline Repeaters & 16 & 30 & 34.78 & & \\
\hline & & & & & \\
\hline Males & 21 & 10 & 67.74 & 1.08 & ns \\
\hline Females & 71 & 57 & 55.47 & & \\
\hline & & & & Sig. at $p=0.05$ \\
\hline Review Center & 74 & 43 & 63.25 & 5.27 & \\
\hline Self-review & 18 & 24 & 42.86 & & \\
\hline $\mathrm{X}^{2}{ }_{0.05,1}=3.84, \mathrm{X}_{0.01,1}^{2}=6.64$ & & & & \\
\hline
\end{tabular}

Source: Philippine Professional Regulations Commission, Board of Librarians 
The higher passing percentage among first timers is not surprising. Such trend has already been established in many reports of licensure examination for teachers (Corpuz and Quinon, 2009; Navarro et al., 2015). However, the higher performance among the first-time takers in this institution contradicts the findings of Ramos et al. (2013) on their analysis of LLE performance of LIS graduates nationwide from 2004 to 2013. The wide scope and the length of time covered could have somehow affected the statistics on the relative performance of first timers and repeaters. This result of this study implies that for the BLIS examinees from 2011 to 2015, repeating the LLE does not put the repeater at an advantage.

The result on statistically similar passing rate among male and female examinees is similar with the findings of Ramos et al. (2013). This means that while there is a common, albeit not proven notion that male librarians are indemand, the sex of the applicant should not be used as a basis in admitting new students in the program.

This study also has proven that attendance to review classes can increase ones chances to hurdle examinations. While the effect of attending review sessions is psychological, it is at times beneficial to many reviewees, especially among social learners. With formal review sessions, reviewees can study with a group, and they have a facilitator who can focus their attention to what is important. It is then the responsibility of review centers to continuously improve their practices. Through constant monitoring, evaluation, and feedback, administrators of review centers should choose reviewers who are experts in the field. They should also focus on competencies the students are weak at. These strategies can increase the examinees' chances in passing examinations.

Considering the performances of graduates on the six examination areas when compared according to examinee variables, results show that the first-timers significantly outperformed the repeaters in all areas, except in Area 4 (Cataloguing and classification). The passing rates were statistically the same in this area. Also, the male examinees had significantly higher passing rates than the females only in Area 1 (Library organization and management). Meanwhile, the examinees who attended review classes performed significantly better only in Area 2 (Reference, Bibliography and User Services) than those who opted to review on their own.

The results of the study on the institutional and performances of each of the subgroups offer valuable information as to how the institution has done its part in preparing future librarians and information professionals. While the institutional performance is higher than $50 \%$, and that of the national data, there is still a need to revisit current practices and see how these practices impact licensure performance. In this state institution, it is difficult to set strict policies on screening and admission, and retention of prospective applicants in the program. However, it should be made clear to the students that there are skills and abilities that each specific degree course require.

This study has also divulged the areas where the examinees are weak, and which subgroups did not perform well. These areas must be emphasized during instruction and during course appraisals and/or reviews. Repeaters should be helped by inviting them for free review classes. Also, review materials and tips on current trends and issues in the field must be given for free, especially to alumni who have graduated much earlier. Likewise, advisers must continuously monitor the performances of the students in all their courses, as these variables may affect the students' future performance in the licensure examinations. Moreover, course appraisal programs must also be strengthened and strictly monitored to allow students to revisit their previous courses. Constant practice and immediate feedback should be provided during course appraisal programs. Graduates must likewise be encouraged to attend review classes. It may also be necessary for faculty members and policy makers to benchmark on the best practices of high performing institutions.

To increase licensure performance, it is necessary to consider many of the student variables that affect learning and performance. But administrative support as to facilities and resources are also contributory to the issue. But administrative support and student variables are useless, without teacher dedication and commitment to mold the students and give them the best education they deserve. 


\section{CONCLUSIONS AND FUTURE DIRECTIONS}

The BLIS graduates who took the LLE from 2011-2015 had posted a statistically consistent result. During the five-year duration, the BLIS alumni/alumnae registered a passing rate that is moderately high. The mean general ratings were slightly lower than the mandated passing rate of $75 \%$. Also, the distribution of ratings was rather wide, although more examinees scored higher than the mean score. Overall, the institutional passing rate surpassed the national passing rate by $45.12 \%$. The relatively easy items, according to the results were from Information Technology, Indexing and Abstracting, and Library Organization and Management. The more difficult items come from the areas of Selection and Acquisition of Library Materials, and in Cataloguing and Classification. Higher passing rates were posted by the first timers in five areas, except in the difficult field of cataloguing and classification. The center-reviewees outperformed the self-reviewees, but most profoundly in library materials acquisition and selection. The male and female examinees did not statistically differ, although the males had higher passing rate in library organization and management.

Based on the results, there is still a need to consider studying and/or revisiting the impact of the present departmental and institutional practices on LLE performance. The problematic areas must be given more focus and emphasis during instruction and review. Graduates must be encouraged to attend review classes, and the institution must do something to reach out to the repeaters. Course appraisal must also be properly monitored and implemented. Moreover, the institution might consider benchmarking on the best practices of top-performing institutions.

Finally, there must be a follow-up study on the impact of other examinee variables, teacher characteristics and administrative support on licensure performance. Furthermore, evaluation and studies should also be conducted on the effect of other intervention programs on licensure results.

Funding: This study received no specific financial support.

Competing Interests: The authors declare that they have no competing interests.

Contributors/Acknowledgement: Both authors contributed equally to the conception and design of the study.

\section{REFERENCES}

Botengan, D.F., A.J. Bansiong and R.B. Kudan, 2016. Licensure examination performance of BSE and BEE graduates of Benguet State University 2010-2014. Unpublished College Research Paper. Benguet State University College of Teacher Education.

Chan-Rabanal, G., 2016. Academic achievement and LET performance of the Bachelor of elementary education graduates, University of Northern Philippines. International Journal of Scientific and Research Publications, 6(6): 455-461.

Corpuz, B.B. and N.V. Quinon, 2009. Comparative study of the LET and teaching performance of education and non-education graduates in the Philippines. PAFTE Journal, 15(1): 2-24.

Ferrer, R.C., D.R. Buted and I.M.C. Ferrer, 2015. Performance of BSED science graduates in licensure examination for teachers: Basis for a regression model. Asia-Pacific Journal of Multidisciplinary Research, 3(5): 1-6. View at Google Scholar

Ladia, M.A.P. and N.R. Nool, 2012. Analysis of the performance in the licensure examination for teachers of State Universities and Colleges in Region from https://www.academia.edu/7963956/Performance_in_the_Licensure_Examination_for_Teachers_of_State_Universiti es_and_Colleges_in_Region_III [Accessed 2/24/17].

Maghuyop, R.B., 2016. To pass or fail: A University of Mindanao librarian licensure performance study. University of Minnesota; International Multi-Resolution Journal, 1(1): 90-104.

Merced, J.B.M. and R.M. Canang, 2014. Determining the factors affecting the passing rate in the board examination for librarians using a web-based instrument. PAARJ Research Journal, 1(1): 1-24. 
Navarro, R.L., P.I. Lucido, P.R. Giron and N.M. Uy, 2015. August 2014 LET results: Evidence of teaching for meaning and mastery? Professional Teacher, 6(2).

Ramos, M.M., A.M. Ananoria and C.M. Nera, 2013. Factors affecting the performance of library and information professionals in the librarians' licensure examination (LLE) 2006-2010. Part 2. Year of graduation, academic degrees, and educational institutions. Journal of Philippine Librarianship, 33(1): 37-46. View at Google Scholar

Ravetter, F. and L.L. Wallnau, 2014. Essentials of statistics for the behavioral sciences. 8th Edn., Belmont, CA: Wadsworth.

Soriano, H.S., 2009. Factors associated with the performance of USM college of education graduates in the 2007 licensure examination for teachers. USM R \& D, 17(2): 151-159. View at Google Scholar

Tan, C.S., 2016. Impact of review on the performance of graduates in the licensure examination for teachers, 2012-2014. EProceedings of the 4th Global Summit on Education.

Tarun, I.M., B.D. Gerardo and B.T. Tanguilig, 2014. Generating licensure examination performance models using PART and JRIp classifiers: A data mining application in education. International Journal of Computer and Communication Engineering, 3(3): 202-207. View at Google Scholar | View at Publisher

Visco, D.A., 2015. Determinants of performance in the licensure for teachers of Abra State institute of sciences and technology. International Journal of Research in Management \& Business Studies, 2(1): 39-44. 